\title{
RODA (ROTATING EDUCATION GAME) SEBAGAI MEDIA PEMBELAJARAN UNTUK MENANAMKAN SIKAP DISIPLIN PADA ANAK USIA DINI
}

\author{
*Triana Rosalina Noor , **Erwin Astutik \\ STAI An Najah Indonesia Mandiri \\ * trianasuprayoga@gmail.com \\ ** erwinastutik99@gmail.com
}

\begin{abstract}
Based on KPAI data, the trend of violence against children in education in 2018 bas increased. Of the total 445 tapes, 51.2 percent or 228 cases were cases of physical, sexual and verbal abuse. In addition, child abuse also occurs at home. Acts of violence against children are carried out on the grounds of disciplining children. Violence experienced by children can have a prolonged psychological effect on bim. The discipline of planting does not have to be done with violence. This then encourages the writer to make RODA (Rotating Education Game) as a learning medium to instill discipline in early childhood. This research uses a qualitative R\&D approach, which is research that is used for certain products and tests its effectiveness. ROD $A$ is a colorful learning media and has a funny character so that it can stimulate children's memories from being disciplined in childhood. According to Albert Bandura this learning is called modeling. Thus it can be concluded, With the existence of ROD $A$ as a media for the formation of a disciplined attitude in early childhood, it can facilitate teachers or parents in the formation of a disciplined attitude so that they can help older children have discipline in carrying out their daily activities.
\end{abstract}

Keywords: Discipline, RODA, Early Childhood

\begin{abstract}
Abstrak : Berdasarkan data KPAI, tren kekerasan pada anak dalam pendidikan pada tahun 2018 telah meningkat. Dari total 445 kaset, 51,2 persen atau 228 kasus adalah kasus kekerasan fisik, seksual dan verbal. Selain itu, kekerasan anak juga terjadi saat di rumah. Tindakan kekerasan terhadap anak dilakukan dengan alasan mendisiplinkan anak. Kekerasan yang dialami oleh anak-anak dapat memiliki pengaruh psikologis yang berkepanjangan pada dirinya. Disiplin penanaman tidak harus dilakukan dengan kekerasan. Hal ini kemudian mendorong penulis untuk menjadikan RODA (Rotating Education Game) sebagai media pembelajaran untuk menanamkan disiplin pada anak usia dini. Penelitian ini menggunakan pendekatan R\&D kualitatif, yaitu penelitian yang digunakan untuk produk-produk tertentu dan menguji efektivitasnya. RODA adalah media pembelajaran yang penuh warna dan memiliki karakter lucu sehingga dapat merangsang ingatan anak-anak untuk dari sikap disiplin pada masa anak-anak. Menurut Albert Bandura pembelajaran ini disebut pemodelan. Dengan demikian dapat disimpulkan, Dengan keberadaan RODA sebagai media pembentukan sikap
\end{abstract}

\author{
As-Sabiqun : Jurnal Pendidikan Islam Anak Usia Dini \\ Volume 1, Nomor 2, Oktober 2019; 1-16 \\ https://ejournal.stitpn.ac.id/index.php/assabiqun
}


disiplin pada anak usia dini, dapat memudahkan guru atau orang tua dalam pembentukan sikap disiplin sehingga mereka dapat membantu anak usia lanjut memiliki disiplin dalam melaksanakan aktivitas kesehariannya.

Kata Kunci : Disiplin, RODA, Early Chilhood

\section{PENDAHULUAN}

Menurut KPAI (Komisi Perlindungan Anak Indonesia) menyatakan bahwa tren kekerasan pada anak dalam bidang pendidikan pada 2018 lalu meningkat. Dari total 445 kasus, sebanyak 51,2 persen atau 228 kasus merupakan kasus kekerasan fisik, seksual dan verbal. Selain itu kekerasan pada anak juga terjadi ketika berada di rumah. ${ }^{1}$ Kekerasan yang dilakukan oleh orang tua atau guru terhadap anak seringkali berdalih bahwa hal tersebut dilakukan merupakan cara mendisiplikan anak. Asumsi yang dimiliki oleh orangtua atau guru bahwasannya jika anak tidak melaksanakan tata aturan dengan baik, maka anak wajib diberikan sanksi atau hukuman. ${ }^{2}$ Tindakan tersebut dapat memberikan dampak negative pada anak dan Kekerasan yang dialami anak dapat memberikan efek psikologis yang berkepanjangan pada dirinya. Penanaman disiplin tidak harus dilakukan dengan kekerasan. ${ }^{3}$

Anak usia dini berada di fase golden age (masa keemasan), karaena masa ini terjadi perkembangan yang sangat cepat, seperti perkembangan fisik dan psikis. Perkembangan fisik berupa perkembangan sel otak dan organ tubuh yang lainnya. Perkembangan psikis pada anak usia dini yaitu, sudah mampu berfikir secara sensori motoris hingga pra operasional konkret. ${ }^{4}$ Pengajaran, pembiasaan atau pendidikan yang dilakukan bagi anak usia dini akan membekas hingga mereka dewasa, sehingga menentukan karakter mereka kedepannya. Karakter merupakan pendidikan yang dilakukan untuk pembentukan tingkah laku seseorang agar sesuai dengan tata aturan moral dalam segi kognitif, afektif dan psikomotor. ${ }^{5}$

1 Ign. L. Adhi Bhaskara. Cara Membesarkan Anak yang Disiplin dan Bahagia. (2019). diambil dari https://tirto.id/dg8r. diakses pada 10 Juli 2019 pukul 11:00

${ }^{2}$ Choirun Nisak Aulina, Penanaman Disiplin Pada Anak Usia Dini. Jurnal Pedagogia Vol. 2, No. 1. (2013). Hal. 36

${ }^{3}$ YulaikaRamadhani. Jangan Ajarkan Disiplin dengan Kekerasan. (2017). Diambil dari https:/ / tirto.id/cxPX Diakses Pada 27 Juni 2019 Pukul 14:07

${ }^{4}$ Masganti Sit, "Psikologi Perkembangan Anak Usia Dini”". (Kencana:Depok, 2017) Hal.6

5 Elly Lanti, "Media Pengembangan Pendidikan Karakter Bagi Siswa Sekolah Dasar". (Athara Samudra) Hal.5 
Penanaman karakter disiplin sangat penting untuk diterapkan pada anak usia dini atau peserta didik, karena melalui pendidikan karakter disiplin akan melatih anak untuk membiasakan diri mereka selalu mengutamakan kedisiplinan dalam kesehariannya. ${ }^{6}$ Disiplin merupakan karakter yang menunjukkan perilaku untuk berbuat patuh dan tertib terhadap tata aturan yang ada, seperti mengerjakan tugas sekolah dengan baik, menggunakan seragam yang telah ditentuakn dan selalu datang tepat waktu. ${ }^{7}$

Peran orang tua dalam pertumbuhan dan perkembangan anak adalah mengarahkan anak agar mampu menjadi generasi yang unggul melalui pengarahan dari orang tua atau guru. Anak usia dini memerlukan lingkungan yang subur agar dapat mendukung pertumbuhan dan perkembangannya secara optimal yang merupakan peran orangtua dalam menciptakan kondisi lingkungan tersebut. ${ }^{8}$ Anak usia dini lebih tertarik pada gambar-gambar atau anaimasi untuk pembelajaran yang menyenangkan dan imajinatif. Sehingga penulis berinisiatif membuat penelitian yang berjudul RODA (Rotating Education Game) sebagai media pembelajaran untuk menanamkan sikap disiplin pada anak usia dini.

Pendidikan karakter disiplin melalui RODA dalam teori Albert Banduara merupaka proses mengikuti dan meniru perilaku dan sikap orang lain dikenal dengan tindakan belajar. Albert Bandura menjelaskan dalam teorinya perilaku manusia dalam konteks interaksi timbal balik yang berkesinambungan Antara kognitif, perilaku dan pegaruh lingkungan. Kondisi lingkungan sekitar individu sangat berpengaruh pada pola belajar social. ${ }^{9}$ Berdasarkan teori tersebut pembuatan media RODA didasarkan pada teori Bandura individu khususnya anak-anak akan mengamati perilaku dilingkungannya sebagai model, kemudian ditirunya sehingga menjadi perilaku yang dimilikinya. ${ }^{10}$

${ }^{6}$ Rianawati, "Implementasi Nilai-Nilai Karakter Pada Mata Pelajaran". (Pontianak:IAIN Pontianak) Hal 37

${ }^{7}$ Atikah Mumpuni, "Integrasi Nilai Karakter Dalam Buku Pelajaran : Analisis Konten Buku Teks Kurikulum 2013”. (Sleman:CV Budi Utama, 2018) Hal 25

${ }^{8}$ Ahmad Susanto, "Perkembangana Anak Usia Dini Pengentar Dalam Berbagai Aspeknya". (Jakarta:Prenadamedia, 2014) Hal.2

${ }^{9}$ Sittah Shofiana Fahriani dan Suharningsih, "Upaya Guru Dalam Menumbuhkan Perilaku Gotong Royong Pada Siswa Di Smp Muhammadiyah 5 Surabaya”, Vol.06, No.01, (2018),

${ }^{10}$ Qurrotul Ainiyah, "Social Learning Theory Dan Perilaku Agresif Anak Salam Keluarga”, Jurnal Al Abkam, Vol.2, No.1, (2017), Hlm.96 
Proses peniruan model dapat dipandang sebagai proses pembentukan karakter. Saat model yang menjadi panutan berperilaku bak maka karakter yang terbentuk pada naka baik. Begitu pula sebaiknya. Model pembelajaran melalui peniruan figure yang diamati melalui media RODA diharapkan dapat membentu orang tua atau guru dalam mengembangkan nilai karakter disiplin pada anak usia dini agar memiliki karakter posistif.

\section{Education Game}

Menurut Vygotsky, kegiatan bermaina pada anak usia dini dapat membantu perkembangan kognitif secara langsung. selain itu bermain simbolik mempunyai peran aktif dalam perkembangan berfikir abstrak. ${ }^{11}$ Kemanpuan kognitif anak dapat ditunjukan dengan cara melaksanakan kegiatan bermain menggunakan alat permainan yang mengandung unsur atau nilai edukatif. ${ }^{12}$

Game merupakan bentuk permainan yang kerap diminati oleh semua kalangan termasuk anakmusia dini. Seringkali dianggap mendatangkan hal negative terhadap anak. Akan tetapi pada kenyataannya, salah satu manfaat game bagi anak yaitu anak akan mampu mengenal teknologi, melatih anak untuk mengikuti pengarahan dan aturan, berlatih untuk memecahkan masalah, melatih saraf motoric, keterampilan spasial dan sebagai sarana hiburan. ${ }^{13}$ Kegiatan bermain, menurut Jean Piaget merupakan latihan bagi anak untuk mengkonsolidasikan pengetahuan serta keterampilan kognitif yang baru dikuasai sehingga dapat berfungsi secara efektif. ${ }^{14}$

Game edukasi merupakan game yang menyisiplkan materi pembelajaran pada permaianan sehingga orang yang memainkan tidak merasa tertekan atau jenuh dengan kegiatan pembelajaran yang serius, serta dirancang khusus untuk tujuan

11 Yuliani Nuraini Sujiono dan Bambang Sujiono, Bermain Kreatif Berbasis Kecerdasan Jamak. (Jakarta:PT Indeks, 2010) Hal. 3

${ }^{12}$ Inggried Claudia Muloke Amatus, Yudi Ismanto dan Yolanda Bataha, "Pengaruh A L At Pe Rmai Nan E Duk At I F ( Puzzle) Terhadap Perkembangan Kognitif Anak Usia 5-6 Tahun Di Desa Linawan Kecamatan Pinolosian Kabupaten Bolaang Mongondow Selatan”, E-Journal Keperawatan(E-Kp), Vol.5, No.1, (2017), Hlm.10

${ }^{13}$ Dian Wahyu Putra, A. Prasita Nugroho Dan Erri Wahyu Puspitarini. Game Edukasi Berbasis Android Sebagai Media Pembelajaran Untuk Anak Usia Dini. Jimp - Jurnal Informatika Merdeka Pasuruan Vol.1, No.1 (2016). Hal.47

14 Ainna Amalia, Metode Pengembangan Kognitif Anak Usia Dini. (Surabaya:Uin Sunan Ampel Press,2018) Hal 
pendidikan. ${ }^{15}$ Game edukasi betujuan untuk menarik minat anak untuk belajar terhadap materi pembelajaran dengan bermain game. ${ }^{16}$ Menurut andang ismail, game edukasi memiliki beberapa fungsi yaitu, adanya proses belajar sambil bermain yang dapat membantu anak memiliki pengetahuan baru, merangsang daya berfikir, daya cipta dan Bahasa agar anak dapat menumbuhkan sikap, mental dan akhlak yang baik, memberikan pengalaman belajar yang menyenangkan sehingga ank tidak cepat bosan dan meningkatkan kualitas pembelajaran pada anak. ${ }^{17}$

\section{Penanaman Karakter Disiplin}

Penanaman adalah proses (perbuaatan atau cara) menanamkan. ${ }^{18}$ artinya, bagaimana usaha seorang menanamkan nilai -nilai dalam hal ini adalah nilai pendidikan karakter yang dilandasi oleh pemahaman terhadap berbagai kondisi pembelajaran yang berbeda -beda. Nilai berasal dari bahasa latin vale're yang artinya berguna, mampu akan berdaya, berlaku, sehingga nilai diartikan sebagai sesuatu yang dipandang baik, bermanfaat dan paling benar menurut keyakinan seseorang atau sekelompok orang. Nilai mengarahkan seseorang untuk bertingkah laku (attitudes), atau bersikap sesuai dengan moralitas masyarakat, jadi nilai itu memberi acuan atau pedoman bagaimana seharusnya seseorang harus bertingkah laku.

Penanaman pendidikan karakter bertujuan untuk membentuk bangsa yang berakhlak mulia, memiliki moral, gotong royong, toleransi, berjiwa patriotic, berkembang dinamis, berjiwa tangguh, kompetitif, berkembang dinamis, orientasi pada ilmu pengetahuan dan teknologi dan pada keseluruhan dijiwai oleh pancasila. ${ }^{19}$ Salah satu pendidikan karakter yaitu sikap disiplin

15 Agus Mulyanto, Apriyadi dan Purwono Prasetyawan. Rancang Bangun Game Edukasi "Matching Aksara Lampung" Berbasis Smartphone Android. Cess Journal Of Computer Engineering System And Science). Vol. 3 No. 1 Januari 2018. Hal. 36

${ }^{16}$ Bonifacio Barros, Fitri Marisa dan Indra Dharma Wijaya. "Pembuatan Game Kuis Siapa Pintar. Jimp - Jurnal Informatika Merdeka Pasuruan”. Vol 3 No 1 (2018). Hal. 45

${ }^{17}$ Haryanto dan Bagas Friana. "Aplikasi Permainan Edukatif Mengaji Berbasis Multimedia Interaktif”. Jurnal Teknik Informatika Unis Jutis. Vol. 6 No.1 (2018). Hal. 10

${ }^{18} \mathrm{KBBI}$ Online diambil dari https://kbbi.web.id/tanam.html

19 Muchlas Samani dan Hariyanto, “Konsep Dan Model Pendidikan Karakter". (Bandung, Pt Remaja Rosda Karya, 2016). Hal. 9 
Disiplin berasal dari kata 'disciple' yang mempunyai artinya seorang yang belajar dari atau secara sukarela mengikuti seorang pemimpin. ${ }^{20}$ Menurut Charles Schaefer disiplin merupakan segala sesuatu yang dilakukan oleh orang dewasa berupa pnegajaran, bimbingan dan dorongan yang bertujuan untuk menjalani kehidupan social serta mampu mencapai pertumbuhan dan perkembangannya secara optimal. ${ }^{21}$ Penanaman karakter disiplin penting untuk diterapkan sejak usia dini agarsupaya dapat berperilaku sesuai dengan atauran atau norma yang ada dimasyarakat dan anggota kelompok social mereka. ${ }^{22}$ Tujuan disiplin bagi anak terbagi atas tujuannjangka pendek (mengajarkan anak agar terlatih dan terkontrol dengan mengajarkan bentuk perilaku pantas dan tidak pantas, sedangkan tujuan jangka panjang berupa membentuk perkembangan dalam mengendalikan diri. ${ }^{23}$

Keberhasilan seseorang dalam masyarakat sebagian besar ditentukan oleh $80 \%$ kecerdasan emosional dan 20\% kecerdasan kognitif. cerminan kecerdasan socialemosional dapat diketahui melalui, perilaku hidup sehat, percaya diri, kerativitas, rasa ingin tahu, mandiri, peduli, mampu bekerjasama, mampu beradaptasi dengan lingkungan sekitar, jujur, santun dan disiplin. Perilaku disiplin merupakan salah satu penunjang keberhasilan seseorang. ${ }^{24}$

\section{Anak Usia Dini}

Anak usia dini adalah individu yang sedang menjali proses suatu perkembangan dengan sangat pesat dan fundamental bagi kehidupan selanjutnya. ${ }^{25}$ Menurut UU SISDIKNAS (Sistem Pendidikan Nasional) menyatakan bahwa anak usia dini berada

${ }^{20}$ Choirun Nisak Aulina, Penanaman Disiplin Pada Anak Usia Dini. Jurnal Pedagogia. Vol. 2, No. 1.(2013). Hal. 37

${ }^{21}$ Choirun Nisak Aulina, Penanaman Disiplin Pada Anak Usia Dini. Hal 38

${ }^{22}$ Choirun Nisak Aulina. Op.Cit. Hal. 2

23 Ernie Martsiswati dan Yoyon Suryono, "Peran Orang Tua Dan Pendidik Dalam Menerapkan Perilaku Disiplin Terhadap Anak Usia Dini”. Jurnal Pendidikan Dan Pemberdayaan Masyarakat. Vol.1 - No. 2 (2014). Hal. 188

${ }^{24}$ Sri Karina Elprida, I Wayan Sujana dan Luh Ayu Tirtayani, "Pengaruh Keterampilan Dasar Mengajar Guru Terhadap Perilaku Disiplin Pada Anak Usia Dini Kelompok B". E-Journal Pendidikan Anak Usia Dini Universitas Pendidikan Ganesha Jurusan Pendidikan Guru Pendidikan Anak. Usia Dini. Vol. 6 No. 1 (2018). Hal. 2

25 Desi Ratnasari, Korelasi Hasil Penerapan Pendidikan Karakter Dan Standar Tingkat Pencapaian Perkembangan Anak Di Kelompok Bermain Batik Sidoarjo. 2015. Diambil Dari https://jurnalmahasiswa.unesa.ac.id/index.php/jurnal-pendidikan-luar sekolah/article/viewFile/11310/10739 Diakses pada 10 Juli 2019 pukul 11:11 
direntan usia 0-6 tahun. ${ }^{26}$ Perkembangana anak yang paling penting berada di fase usia dini, karena pada tahapan ini anak mengalami perkembangan yang paling pesatbaik secara fisik dan mental. 80 persen perkembangan otak anak usia dini melebihi orang dewasa. Sehingga disebut sebagai masa keemasan (golden age). ${ }^{27}$

Golden age merupan sebuah masa yang dialami oleh setiap anak pada usia dini, karena terjadinya perkembangan terbaik serta menakjubkan pada anak usia dini. yang mencangkup perkembangan fisik, yaitu adanya pertumbuhan sel-sel otak dan organ psikis lainnya dan perkembangan kemampuan motoric kasar seperti berlari, memanjat dan melompat. Sedangkan perkembangan fisik yang meliputi motoric halus yaitu melakukan koordinasi matan dan tangan meremas dan menulis. ${ }^{28}$ Peran keluarga khususnya orang tua pada anak usia dini yaitu harus mampu menstimulasi perkembangan kecerdasan anak usia dini sebagai wujud pembentukan karakter positif. Pembentukan karakter positif secara optimal tidak terbentuk jika hanya distimulasi pada anak usia dini. Sehingga harus memperhatikan anak usia dini pada perkembangan selanjutnya. ${ }^{29}$

Menurut John Lock dalam teori tabularasa yang dikemukakan olehnya, bahwa seorang anak lahir dalam keadaan seperti kertas putih yang tidak berdaya dan tidak memiliki apa-apa. Lingkungan yang berada di sekitar anak sangat berpengaruh terhadap tumbuh kembangnya. lingkungan yang berada disekitar anak akan membrikan isi atau warna sebagai bentuk pengalaman. Melalui pengalaman saat berada dilingkungan tersebut, akan terbentuk pada anak pola piker dan karakter atau sifat alami. Sehingga, untuk mendapatkan pelajaran dari lingkungan anak perlu mendapatkan pelatihan sensori yang bertujuan untuk kesiapan belajar yang nantinya akan mempengaruhi kesiapan belajar pada anak untuk masa depannya. ${ }^{30}$

Pada perkembangan anak usia dini, melalui aspek pendidikan adanya stimulus sangat diperukan dalam memberikan suatu rangsangan ada perkembangan anak yang

${ }^{26}$ Dewey John, "Pengertian Anak Usia Dini Menurut Beberapa Cindikiawan”. Diambil Dari Silabus.Web.Id Diakses pada 16 Juni 2019 Pukul 21:59

${ }^{27}$ Lia Lica P dan Dian Eka Priyantoro. "Manajemen Pendidikan Karakter AUD”. Jurnal Ilmiah Pendidikan Islam Anak Usia Dini. Vol. 2. No. 1. (2007). Hal: 30

${ }^{28}$ Masganti Sit. "Psikologi Perkembangan Anak Usia Dini”. (Kencana:Depok,2017). hal:5

${ }^{29}$ Miftahul Achyar Kertamuda, "Golden Age Strategi Sukses Membentuk Karakter Emas Pada Anak Sejak Usia Dini”. (PT. Elix Media Komputindo : Jakarta,2015). hal. 4

30 Anita Yus, "Model Pendidikan Anak Usia Dini". (Jakarta:Prenadamedia Group, 2011). Hal.3 
meliputi, pencapaian nilai-nilai dasar berupa budi pekerti dan agama, sikap atau karakter (disiplin dan kemandirian dan yang terakhir pengembangan kemampuan dasar yang meliputi motorik, kognitif, social dan Bahasa. ${ }^{31}$

\section{METODE PENELITIAN}

Tujuan penelitian ini adalah menghasilkan media pembelajaran yang bisa digunakan dalam menanamkan sikap displin pada anak usia dini. Guna mencapai tujuan tersebut digunakan model penelitian dan pengembangan atau Research \&Development (R\&D). Melalui model penelitian dan pengembangan diharapkan diperoleh suatu produk yang sebagai media pembelajaran pada nantinya.

Sukmadinata mengatakan "Penelitian dan Pengembangan (Research and Development) adalah suatu proses atau langkah - langkah untuk mengembangkan suatu produk baru atau menyempurnakan produk yang telah ada, yang dapat dipertanggungjawabkan". Lebih lanjut Sukmadinata mengemukakan "Langkah langkah penelitian dan pengembangan menunjukkan suatu siklus, yang diawali dengan adanya kebutuhan, permasalahan yang membutuhkan pemecahan dengan menggunakan suatu produk tertentu". ${ }^{32}$ Menurut Sujadi, Penelitian dan Pengembangan atau Research and Development (R\&D) adalah suatu proses atau langkah-langkah untuk mengembangkan suatu produk baru, atau menyempurnakan produk yang telah ada, yang dapat dipertanggungjawabkan. ${ }^{33}$

\section{HASIL DISKUSI DAN PEMBAHASAN}

RODA (Rotating Education Game) sebagai media pembelajaran untuk menanamkan sikap disiplin pada anak usia dini.

Anak usia dini merupakan investasi bagi bangsa. Negara yang maju dimulai dari pendidikan yang mempunyai integritas, nasionalisme dan karakter yang kuat dimulai sejak usia dini. ${ }^{34}$ Salah satu pendidikan karakter yang harus dikuatkan adalah sikap

31 J.M. Tedjawati, "Peran HIMPAUDI Dalam Pengembangan PAUD. Jurnal Pendidikan Dan Kebudayaan, Vol. 17, No. 1 (2011). Hal. 124

32 Nana Syaodih Sukmadinata, Metode Penelitian Pendidikan, (Bandung : PT Remaja Rosdakarya, 2011), hal. 164-165.

${ }^{33}$ Sujadi, Metodologi Penelitian Pendidikan, (Jakarta. Rineka cipta, 2008),hal. 164.

34 Slamet Suyanto, Pendidikan Karakter Untuk Anak Usia Dini. Jurnal Pendidikan Anak, Vol.1, No. 1 (2012). Hal. 1 
disiplin. Disiplin merupakan salah satu kebutuhan dasar bagai anak usia dini yang bertujuan dalam pembentukan dan pengembanagn wataknya secara sehat. ${ }^{35}$ Sikap disiplin dapat menjadikan individu melaksanakan tanggung jawab dan tugas dengan tertib dan teratur sesuai etika serta aturan yang berlaku dimasyarakat. ${ }^{36}$

Kedisiplinan merupakan hal yang penting untuk diajarkan oleh orantua kepada anaknya sejak usia dini. Menurut Annelia Sari Sari, seorang psikolog dari tiga generasi menyampaikan bahwa kedisiplinan tidak harus diajarkan ketika sudah dewasa, akan tetapi dilakukan sejak lahir atau usia dini. Ketika orang tua membiasakan anak dengan kedisiplinan. Maka, setelah menginjak usia dewasa hal tersebut akan terus berlangsung. Sehingga sikap atau aktifitas anak dalam kesehariannya akan lebih terkontrol. $^{37}$

Anak usia dini yang sudah terbiasa dengan sikap disiplin, maka anak tersebut dapat mengarahkan dirinya tanpa pengaruh atau pengarahan dari orang lain. Dapat disimpilkan bahwa ketika anak usia dini mampu menerapkan perilaku disiplin berarti anak sudah mampu menguasai tingkahlakunya dengan berpedepan terhadap etika, norma, standart aturan yang sudah milik sendiri yang akan dapat menumbuhkan sikap tanggungjawab pada anak tersebut. Berdasarkan hal tersebut factor eksternal salah satuna dukungan dan dorongan dari orang tua sangata mempengaruhi terhadap keberhasilan penerapan sikap disiplin tersebut. Sehingga harus mengembangkan dan mengarahkan anak. ${ }^{38}$

RODA merupakan media pembelajaran yang didesain untuk anak usia dini dan digagas oleh penulis berupa lingkaran yang berisi gambar nilai-nilai perilaku disiplin. RODA berbahan dasar triplek. Disisi lain, mempunyai ketahanan yang kuat tidak

35 Nyoman Rohmaniah, I Made Tegeh dan Mutiara Magta. Penerapan Teknik Modifikasi Perilaku Token Economy Untuk Meningkatan Kedisiplinan Anak Usia Dini. E-Journal Pendidikan Anak Usia Dini. Vol.4. No. 2 (2016). Hal.2

${ }^{36}$ Destya Dwi Trisnawati, Membangun Disiplin Dan Tanggung Jawab Siswa Sma Khadijah Surabaya Melalui Implementasi Tata Tertib Sekolah. Jurnal Kajian Moral dan Kewarganegaraan No.1. Vol.2 (2013). Hal. 399

${ }^{37}$ Ajeng Anastasia Kinanti. Pentingnya Mengajarkan Disiplin Pada Anak Sejak Dini. (2017) Https://Health.Detik.Com/Ibu-Dan-Anak/D-3407075/Pentingnya-Mengajarkan-Disiplin-PadaAnak-Sejak-Dini

${ }^{38}$ Direktorat Pembinaan Pendidikan Anak Usia Dini. Direktorat Jenderal Pendidikan Anak Usia Dini Nonformal Dan Informal Kementerian Pendidikan Nasional Tahun 2011. Hal.8 Diambil Dari Http://Paud.Kemdikbud.Go.Id/Wp-Content/Uploads/2016/04/Disiplin-Pada-Anak-File.Pdf Diakses Pada 9 Juli 2019 Pukul 21:21 
mudah berubah bentuk, harga yang ekonomis, tidak terlalu tebal banyak variasi sesuai keinginan dan juga ringan sehingga mudah untuk dibawa ke tempat manapun.

RODA berasal dari bahan dasar triplek yang kemudian di desain dengan ukuran berbentuk lingkran. Triplek merupakan bahan dasar yang aman untuk digunakan pada anak usia dini. RODA menggunakan gambar-gambar animasi yang disesuaikan dengan usia anak dini. Selain itu RODA didesain dengan gambar lucu dan warna-warni sehingga akan menstimulus ingatan anak untuk membentuk karakter disiplin pada anak usia dini. media pembelajaran RODA menggunakan nilainilai yang berbentuk symbol berupa kartun yang dikhususkan untuk anak usia dini sejalan dengan teori yang dikemukakan oleh Piaget bahwa, pada usia 2-7 pada tahap praoperasional anak mulai bermaian kreatif. pada tahap usia ini anak usia dini sudah mamiliki gambaran jiwa, mengenal dirinya, menggunakan symbol. Kegiatan manipulasi symbol akan membantu anak berfikir dasar, bermain kreatif tersebut dapat berupa permainan menggunakan kata, menulis kata dan gambar. ${ }^{39}$

RODA dapat mendorong anak mengembangkan kecerdasan jamak berupa visual spasial yaitu, berfikir melalui gambar berupa symbol atau gambar disiplin, menvisualisasikan presentasi tiga dimensi berupa bentuk permainan RODA yang berbentuk 3 dimensi dan menggunakan imajinasi pada bagian ini media RODA akan mengajak anak usia dini untuk berimajinasi, ${ }^{40}$ Didukung dengan adanya gambar yang disesuaikan dengan anak usia dini serta memiliki warna yang beraneka ragam. sehingga menjadikan RODA sebagai media pembelajaran yang cocok untuk digunakan dalam menanamkan nilai-nilai disiplin pada anak usia dini. Adapun contoh RODA sebagaimana berikut :

${ }^{39}$ Yuliani Nuraini Sujiono Dan Bambang Sujiono, Bermain Kreatif Berbasis Kecerdasan Jamak. (Jakarta:PT Indeks, 2010) Hal. 35

${ }^{40}$ Yuliani Nugroho dan Abmbang, Bermain Kreatif Berbasis Kecerdasan Jamak. Hal 56 


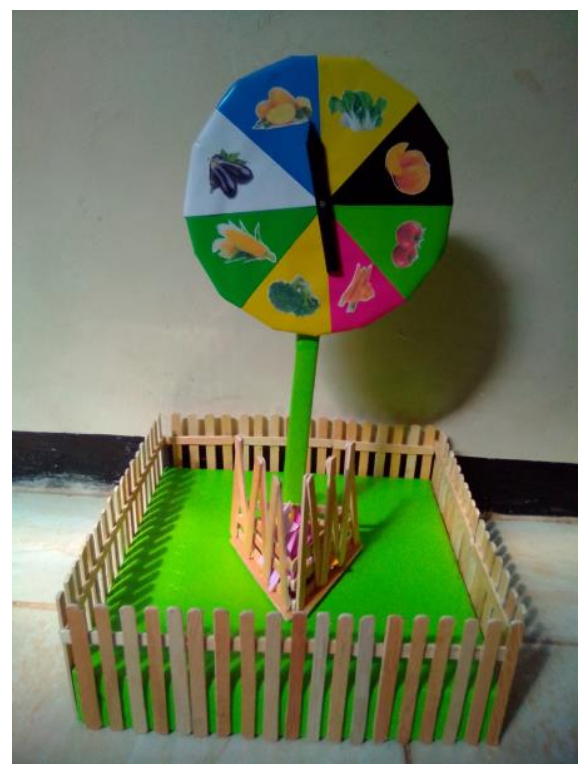

Gambar 1 : Contoh media RODA

Dengan demikian penanaman karakter disiplin pada anak usia dini yang sedang berada difase golden age akan akan mudah dilakukan. sebab karakter disiplin sangat penting untuk diterapkan sejak usia dini. agar supaya setelah menginjak usia dewasa. karakter tersebut sudah dapat diterapka dalam kehidupan sehari-hari. pembentukan nilai-nilai karakter positif dapat diintegrasikan melalui proses pembelajaran dikelas ataupun dengan kegiatan pembiasaan. kegiatan pembiasaan merupakan tindakan yang dilakukan secara terus-menerus dalam kegiatan sehari-hari seorang individu akan mampu membentuk karakter pada individu tersebut. ${ }^{41}$ Melalui media RODA anak akan terbiasa menggunakan media tersebut serta dengan pembiasaan pembelajaran secara terus-menerus, secara tidak langsung akan terbentuk karakter disiplin pada anak usia dini dibuktikan dengan sikap disiplinya dalam kehidupan sehari-hari. Pembentukan nilai-nilai karakter tersebut dapat diintegrasikan melalui proses pembelajaran di kelas ataupun dengan kegiatan pembiasaan. Kegiatan pembiasaan merupakan tindakan yang dilakukan secara terusmenerus dalam kegiatan sehari-hari individu maka akan terbentuk karakter individu tersebut.

Keunggulan lain dari media pembelajaran RODA yaitu lingkaran yang digunakan untuk menanamkan nilai-nilai disiplin dapat diganti dengan nilai-nilai yang

${ }^{41}$ Febrina Evananda, Ibrahim Bafadal dan Ahmad Yusuf Sobri, "Studi Kasus Implementasi Pendidikan Karakter Pada Sekolah Dolan", JAMP (Jurnal Administrasi dan Menejemen Pendidikan), Vol.1, No.3, (2018), hlm.256 
lain. Jika guru atau orangtua ingin menggantinya dengan mengenalkan suatu objek, benda atau nilai karakter nantinya yang disesuaikan dengan tema kegiatan atau sentra permainan di sekolah. sehingga anak tidak akan cepat bosan dan RODA dapat dijadikan sebagia permainan multifunfsi.

Media pemebelajaran pada anak usia dini dapat dijadikan bahan informasi dan alat bermain yang akan membuat anak usia dini memperoleh sebuah pengetahun, keterampilan dan sebuah sikap. RODA adalah media pembelajaran berbentuk lingkaran yang digunakan untuk meanamkan sikap disiplin pada anak usia dini . Berdasarkan teori yang dikemukakan oleh Bandura anak akan meniru figure yang menarik dan mirip dengan dirinya. media RODA didesain dengan menggunakan gambar animasi lucu serta gambar memiliki gambar yang berwarna-warni. Sehingga akan mampu menarik minat anak usia dini untuk menggunaknnya.

Peran media RODA dalam menumbuhakan sikap disiplin pada anak usia dini, berasal dari kemampuan RODA dalam mengembngakn kemmapuan kognitif karena, ketika anak usia dini sering dihadapkan pada suatu objek, maka akan semakin banyak pula pikiran dan pengetahuan yang dimilikinya. ${ }^{42}$ Konsep pembelajaran pada media RODA menekankan pada proses pengenalan pada anak dengan benda. Proses pengenalan anak harus dilakukan dengan berbagai benda yang akan mendorong anak untuk tertarik terhadap berbagai hal atau persoalan. Sehingga menjadikan anak belajar lebih lanjut.

Berdasarkan gambar tersebut, dapat dijelaskan bahwa RODA berisi nilai-nilai sikap disiplin yang harus anak sebutkan atau menjabarkan perilaku seperti apa yang terdapat dalam gambar. selain itu media pembelajaran menggunakan RODA akan melatih anak untuk bersikap suportif karena ketika anak mampu menjawab atau menjabarkan nilai karakter yang terdapat dalam permainan RODA, maka anak akan mendapatkan reword berupa bintang. hal ini juga kana turut mendorong anak untuk memainkan karena RODA didesain dalam bentuk permainan yang menyenangkan.

Menurut teori Albert Bandura, ada empat sub-proses yang menentukan belajar observasional yaitu, (proses attentional) proses mengamati, (proses retention) merupakan proses penyimpanan suatu hal yang diamati kedalam fikiran. (proses

42 Ainna Amelia Dkk, Metode Pengembangan Kognitif Anak Usia Dini. (Surabaya:UIN Sunan Ampel Press, 2018). Hal 242 
production) proses pengolahan yang akan disimpan dalam otak, (proses motivational) proses motivasi. ${ }^{43}$

Pada proses perhatian (attentional), anak akan mulai mengamati figure yang diamati, agar proses tersebut tercapai maka gambar yang terdapat dalam RODA didesain dengan gambar yang menarik, berwarna dan lucu yang disesuaikan dengan karakter anak usia dini. Setelah anak mengamati maka pada tahap selanjutnya, anak mulai memproses makna atau maksud gambar figure yang diamati kedalam fikiran, setelah tahap tersebut anak mulai berada pada tahap (production), anak mulai mengolah gambar yang diamati kedalam fikiran untuk menghasilkan suatu tindakan dan pada tahap terakhir yaitu (motivation), pada tahap ini anak akan mulai termovasi untuk melakukan sesuai dengan figure yang telah diamati. Agar proses motivasi berjalan dengan baik, maka media pembelajaran RODA didesain dengan alur permainan yang menyenangkan. selain itu, disisi lain juga dilengkapi dengan bentuk dan beraneka ragam warna yang akan mampu menarik minat anak usia dini untuk memainkan.

Dapat dilihat bahwa, sikap disiplin pada anak usia dini dibentuk dari bebrapa proses yaitu, proses perhatian (dalam tahap ini anak memainkan RODA sekaligus akan memperhatiakan gambar-gambar yang terdapat dalam RODA, proses penyimpanan dalam ingatan (setelah selesai memainkan media RODA anak usia dini akan menyimpan makna atau pesan dan kesan yang terdapat dalam permainan RODA, proses penyimpanan yang nantinya akan dikelolah oleh otak untuk kemudian menghasilkan sebuah perilaku disiplin, dan yang terakhir proses motivasi (pada proses ini anak usia dini akan mulai melakukan sikap disiplin sesuai dengan gambar yanag terdapat dalam RODA.

Proses pembelajaran melalui media RODA akan membentu anak untuk melatih dan mengembangkan kemampuan kognitif yang dimilikinya. sehingga akan melahirkan sebuah pengetahuan baru yang mampu mencerminkan karakter positif berupa sikap disiplin pada anak usia dini.

${ }^{43}$ I Made Rustika, Efikasi Diri: Tinjauan Teori Albert Bandura. Bulletin Psikolog. Vol. 20, No. 1-2, (2012). Hal 20 


\section{KESIMPULAN}

RODA (Rotating Education Game) sebagai media pembelajaran untuk menanamkan sikap disiplin pada anak usia dini. Merupan media pembelajaran yang berbentuk lingkarang dan berisi nilai-nilai karakter disiplin yang digunakan untuk menanamkan karakter disiplin pada anak usia dini. RODA berbahan dasar triplek sehingga aman bagi anak usia dini. selain itu media RODA didesain dengan bentuk yang lucu seklaigus warna-warni sehingga akan menstimulus anak untuk selalu memainkannya. Sikap disiplin pada anak usia dini dibentuk dari bebrapa proses yaitu, proses perhatian (dalam tahap ini anak memainkan RODA sekaligus akan memperhatiakan gambar-gambar yang terdapat dalam RODA, proses penyimpanan dalam ingatan (setelah selesai memainkan media RODA anak usia dini akan menyimpan makna atau pesan dan kesan yang terdapat dalam permainan RODA, proses penyimpanan yang nantinya akan dikelolah oleh otak untuk kemudian menghasilkan sebuah perilaku disiplin, dan yang terakhir proses motivasi (pada proses ini anak usia dini akan mulai melakukan sikap disiplin sesuai dengan gambar yanag terdapat dalam RODA. Berdasarkan hal tersebut karakter disiplin akan mudah untuk ditanamkan. Sehingga akan terbentuk karakter disiplin pada aktifitas anak usia dini

\section{DAFTAR PUSTAKA}

Aulina, Choirun Nisak.2017. Penanaman Disiplin Pada Anak Usia Dini. Jurnal Pedagogia Vol. 2, No. 1.

Ainiyah, Qurrotul. 2017. Social Learning Theory Dan Perilaku Agresif Anak Salam Keluarga. Jurnal Al Ahkam, Vol.2, No.1

Aulia, Choirun Nisak. 2013. Penanaman Disiplin Pada Anak Usia Dini. Jurnal Pedagogia. Vol. 2, No. 1

Amalia, Ainna dkk. 2018. Metode Pengembangan Kognitif Anak Usia Dini(Surabaya:Uin Sunan Ampel Press)

Amatus, Inggried Claudia Muloke,Ismanto, Yudi dan Bataha, Yolanda. 2017. Pengaruh Alat Permainan Edukatif (Puzzle) Terhadap Perkembangan Kognitif Anak Usia 5-6 Tahun Di Desa Linawan Kecamatan Pinolosian Kabupaten Bolaang Mongondow Selatan. E-Journal Keperawatan(E-Kp), Vol.5, No.1

Bhaskara, Ign. L. Adhi. 2019. Cara Membesarkan Anak yang Disiplin dan Bahagia. Diambil dari https://tirto.id/dg8r 
Barros, Bonifacio. Marisa, Fitri dan Wijaya Indra Dharma. 2018. Pembuatan Game Kuis Siapa Pintar. Jimp - Jurnal Informatika Merdeka Pasuruan. Vol.3 No.1

Direktorat Pembinaan Pendidikan Anak Usia Dini. Direktorat Jenderal Pendidikan Anak Usia Dini Nonformal Dan Informal Kementerian Pendidikan Nasional Tahun 2011. Diambil Dari Http://Paud.Kemdikbud.Go.Id/WpContent/Uploads/2016/04/Disiplin-Pada-Anak-File.Pdf

Elprida, Sri Karina Elprida. Sujana, I Wayan dan Tirtayani, Luh Ayu. 2018. Pengaruh Keterampilan Dasar Mengajar Guru Terhadap Perilaku Disiplin Pada Anak Usia Dini Kelompok B”. E-Journal Pendidikan Anak Usia Dini Universitas Pendidikan Ganesha Jurusan Pendidikan Guru Pendidikan Anak Usia Dini. Vol. 6 No. 1

Evananda, Febrian. Bafadal, Ibrahim dan Sobri, Ahmad Yusuf. 2018. Studi Kasus Implementasi Pendidikan Karakter Pada Sekolah Dolan. JAMP (Jurnal Administrasi dan Menejemen Pendidikan), Vol.1, No.3

Fahriani, Sittah Shofiana dan Suharningsih. 2018. Upaya Guru Dalam Menumbuhkan Perilaku Gotong Royong Pada Siswa Di Smp Muhammadiyah 5 Surabaya", Vol.06, No.01

Haryanto dan Friana, Bagas. 2018. Aplikasi Permainan Edukatif Mengaji Berbasis Multimedia Interaktif. Jurnal Teknik Informatika Unis Jutis. Vol. 6 No.1

John, Dewey. 2019. Pengertian Anak Usia Dini Menurut Beberapa Cindikiawan”. Diambil Dari Silabus.Web.Id

Kartamuda, Miftahul Achyar Kertamuda. 2015. Golden Age Strategi Sukses Membentuk Karakter Emas Pada Anak Sejak Usia Dini. PT. (Elix Media Komputindo : Jakarta)

KBBI Online diambil dari https://kbbi.web.id/tanam.html

Lanti, Elly. Media Pengembangan Pendidikan Karakter Bagi Siswa Sekolah Dasar. (Athara Samudra)

Lica P, Lia dan Priyantoro, Dian Eka. 2007. Manajemen Pendidikan Karakter AUD. Jurnal Ilmiah Pendidikan Islam Anak Usia Dini. Vol. 2. No. 1

Mumpuni, Atikah. 2018. Integrasi Nilai Karakter Dalam Buku Pelajaran : Analisis Konten Buku Teks Kurikulum 2013. (Sleman:CV Budi Utama)

Martsiswati, Ernie dan Suryono, Yoyon. 2014. Peran Orang Tua Dan Pendidik Dalam Menerapkan Perilaku Disiplin Terhadap Anak Usia Dini. Jurnal Pendidikan Dan Pemberdayaan Masyarakat. Vol.1. No. 2

Mulyanto, Agus. Apriyadi dan Prasetyawan, Purwono. 2018. Rancang Bangun Game Edukasi "Matching Aksara Lampung" Berbasis Smartphone Android. Cess (Journal Of Computer Engineering System And Science). Vol. 3 No. 1

Putra, Dian Wahyu Putra. Nugroho, A. Prasita dan Puspitarini, Erri Wahyu. 2016. Game Edukasi Berbasis Android Sebagai Media Pembelajaran Untuk Anak Usia Dini. Jimp - Jurnal Informatika Merdeka Pasuruan Vol.1, No.1 
Rianawati. Implementasi Nilai-Nilai Karakter Pada Mata Pelajaran. (Pontianak:IAIN Pontianak)

Rustika, I Made. 2012. Efikasi Diri: Tinjauan Teori Albert Bandura. Bulletin Psikolog. Vol. 20, No. 1-2

Ramadhani, Yulaika. 2017. Jangan Ajarkan Disiplin dengan Kekerasan. (2017). Diambil dari https://tirto.id/cxPX

Ratnasari, Desi. 2015. Korelasi Hasil Penerapan Pendidikan Karakter Dan Standar Tingkat Pencapaian Perkembangan Anak Di Kelompok Bermain Batik Sidoarjo. Diambil Dari https://jurnalmahasiswa.unesa.ac.id/index.php/jurnalpendidikan-luar sekolah/article/viewFile/11310/10739

Rohmaniah, Nyoman. Tegeh, I Made dan Magta, Mutiara. 2016. Penerapan Teknik Modifikasi Perilaku Token Economy Untuk Meningkatan Kedisiplinan Anak Usia Dini. E-Journal Pendidikan Anak Usia Dini. Vol.4. No. 2

Sugiyono. 2015. Penelitian kuantitatif, kualitatif dan R\&D. (Bandung:ALFABETA)

Suyanto, Slamet suyanto, strategi pendidikan anak. 2018. (Yogyakarta:Hikayat Publishing)

Sujiono, Yuliani Nuraini dan Sijiono, Bambang. 2010. Bermain Kreatif Berbasis Kecerdasan Jamak. (Jakarta:PT Indeks)

Samani, Muchlas dan Hariyanto. 2016. Konsep Dan Model Pendidikan Karakter. (Bandung, Pt Remaja Rosda Karya)

Sit, Masganti. 2017. Psikologi Perkembangan Anak Usia Dini. (Depok: Kencana)

Susanto, Ahmad. 2014. Perkembangana Anak Usia Dini Pengentar Dalam Berbagai Aspeknya. (Jakarta:Prenadamedia)

Tedjawati, J.M. 2011. Peran HIMPAUDI Dalam Pengembangan PAUD. Jurnal Pendidikan Dan Kebudayaan, Vol. 17, No. 1

Yus, Anita. 2011. Model Pendidikan Anak Usia Dini. (Jakarta:Prenadamedia Group) 